\title{
ARTICLE
}

\section{Bycatch of the squat lobster Munida gregaria in bottom trawl fisheries in San Jorge Gulf, Argentina}

\author{
Capturas incidentales de langostilla Munida gregaria en pesquerías \\ de arrastre en el Golfo San Jorge, Argentina
}

\begin{abstract}
Martin Varisco ${ }^{1,2}$, Julio H. Vinuesa ${ }^{1,2}$ and María E. Góngora ${ }^{2,3}$
${ }^{1}$ Universidad Nacional de la Patagonia San Juan Bosco, Ruta Provincial 1, Km. 4, Comodoro Rivadavia, Chubut, Argentina. martinvarisco@ hotmail.com

${ }^{2}$ Centro de Investigación y Transferencia Chubut, Consejo Nacional de Investigaciones Científicas y Técnicas, Ruta Provincial $1, \mathrm{Km} \mathrm{4}, 4^{\circ}$ piso (oficina 460), Comodoro Rivadavia, Chubut, Argentina

${ }^{3}$ Secretaría de Pesca de la Provincia de Chubut, Belgrano 778 ( $1^{\circ}$ piso), Rawson, Chubut, Argentina

Resumen.- Varias especies de langostillas son reconocidas como recursos pesqueros potenciales en todo el mundo. La langostilla Munida gregaria es un componente importante de las capturas incidentales en las pesquerías de arrastre en la Patagonia Argentina. Se evaluó la frecuencia de ocurrencia (FO), abundancia relativa (AR) y destino de las capturas incidentales de M. gregaria en: a) la flota congeladora tangonera (63579 lances), b) la flota fresquera de altura (5608) y c) la flota costera (584). Las mayores FO y AR fueron registradas en la flota costera. Sin embargo, dada la magnitud de la flota congeladora tangonera, el esfuerzo de pesca sugiere que las mayores capturas incidentales en términos de biomasa son producidas por esta flota. Se observó un incremento significativo en FO y AR en los lances de la flota congeladora tangonera en los últimos años, siendo éste más marcado en aguas nacionales y provinciales de la provincia de Santa Cruz. La FO y AR de la especie en los lances de la flota fresquera de altura fueron bajas durante todo el periodo analizado. Los resultados confirman que la langostilla es una especie muy abundante y un recurso desaprovechado hasta el presente, y que puede representar una alternativa para la flota costera en el Golfo San Jorge.
\end{abstract}

Palabras clave: Langostilla, capturas incidentales, pesquerías de arrastre, recurso pesquero

\begin{abstract}
Squat lobsters are recognized as potential fishery resources in many countries. Squat lobster Munida gregaria is an important component of the bycatch in trawling fisheries of Argentinian Patagonia. The frequency of occurrence (FO), relative abundance (RA) and fate of the incidental catch of $M$. gregaria in: a) double-beam trawler fleet (63579 hauls), b) high-seas ice trawler fleet (5608) and c) coastal fleet (584) were evaluated. The highest values of FO and RA were recorded in the coastal fleet. However, given the size of the double-beam trawler fleet, the fishing effort level suggests that the highest captures in terms of biomass are obtained by this fleet. A significant increase in RA and FO was recorded in hauls of double-beam trawler fleet in the last years. Lower FO and RA were recorded in hauls of the high-seas ice trawler fleet. Our results confirmed that squat lobster is abundant and so far not exploited resource and represents an alternative resource for the coastal fleet in San Jorge Gulf.
\end{abstract}

Key words: Squat lobsters, bycatch, trawling, potential resource

\section{INTRODUCTION}

Bottom trawling has been the focus of many studies due to its low selectivity and high incidental catch (Andrew \& Pepperell 1992, Stobuzki et al. 2001). Discards have ecological, legal and socio-economic implications, because reducing the bycatch is one of the main challenges in fisheries management (Kelleher 2008). Describing and characterizing the bycatch is the first step to understand, and eventually manage, the impact of discards on marine communities and on non-target species. Main efforts have been directed towards the charismatic fauna, target species of other fisheries and extinction of endangered species; those efforts have ignored the catch of non-commercial fish and the catch and discards of high invertebrate biomass (Stobuzki et al. 2001, Kelleher 2008). This approach contrasts with the ecosystem approach to fisheries management proposed by FAO, which seeks responsible fisheries considering the wider effects of the activity on the ecosystem as a whole (FAO 2003). On the other hand, the need to satisfy a growing demand leads to the use of unutilized species, including bycatch species (Sato 1974). 
Squat lobsters have a wide distribution, are very abundant, and are recognized as potential fishery resources (for review, see Wehrtmann \& Acuña 2011). The squat lobsters Pleuroncodes monodon (Milne Edwards) and Cervimunida johni (Porter) have been subject to commercial fishery in Chile for over 5 decades. Previously, these species were captured as bycatch of the common hake fishery in the Pacific Ocean. The munidid P. planipes is one of the main species in the deepwater shrimp bycatch in Costa Rica (Wehrtmann \& Acuña 2011). The squat lobster Munida rugosa (Fabricius) is a common crustacean species in the lobster fishery in Scotland (Bergmann \& Poore 2001). The squat lobsters M. rugosa and M. rutllanti Zariquiey-Álvarez are important bycatch components in trawling fisheries in the Cantabrian region and northwest Spanish and Portuguese coasts. Currently, the Spanish government promotes the consumption of squat lobster to deal with the crisis in the fishing industry in that country (CSIC 2014).

Many works have mentioned that the squat lobster Munida gregaria (Fabricius) is abundant in the bycatch of the Patagonian red shrimp Pleoticus muelleri (Bate) fishery in San Jorge Gulf. Incidental catch of squat lobster in this fishery was estimated at 3000 tons in 2004 (Pettovello 1999, Roux \& Piñero 2006, Varisco \& Vinuesa 2007). However, the bycatch of this species has not been quantified or characterized so far. Currently, the incidental catches of this species are monitored by the government of the province of Chubut through an on board observers program (POBCh). The observers monitored hauls in Patagonian shrimp fishery (double-beam trawler fleet), hake fishery (high-sea ice trawler fleet) and coastal fishery (coastal fleet). Particularly, fishermen consider the squat lobster as a factor that may negatively affect the shrimp fishery and the quality of the product obtained. The shrimp fishery is the main crustacean fishery in the Southwestern Atlantic Ocean (Boschi 1997).

Commercial exploitation of $M$. gregaria has been suggested in several localities such as New Zealand (Zeldis 1985), Beagle Chanel (Vinuesa 1990, Lovrich et al. 1999, Tapella 2002), and Magellan Strait (Rodríguez \& Bahamonde 1986), mainly encouraged by the abundance of the species. The potential use of the species is encouraged by the possibility of different uses for the catch. The yield of the squat lobster meat is similar to that of the two species that are exploited in Chile (Lovrich et al. 1999, Alarcón et al. $2003^{1}$ ). Also, squat lobster can also be used in the preparation of diet supplements, as a source of astaxanthin for aquaculture and to obtain chitin, among other applications (Sato 1974, Zeldis 1985, Aurioles-Gamboa \& Balart 1995, Tapella 2002).

The aim of this work is to describe squat lobster bycatch and analyze its seasonal and geographic variation in the bottom trawling fisheries of the San Jorge Gulf and its adjacent area. The frequency of occurrence, relative abundance and fate of the incidental catch of $M$. gregaria in bottom trawling fisheries were evaluated. The potential commercial exploitation of this species is also discussed.

\section{Materials AND METHODS}

\section{STUdY AREA}

San Jorge Gulf (SJG) is the widest sea entry of the southwestern Atlantic Ocean, it extends from Dos Bahías Cape in the north to Tres Puntas Cape in the south. The SJG's water, is a mixture of subantarctic water from the Cape Horn Current and low-salinity water of the Magellanic plume. The latter, formed by the discharge from Magellan Strait, extends along the inner shelf of southern Patagonia (Palma et al. 2008). Its maximum depth is approximately $100 \mathrm{~m}$. The maximum and minimal temperatures oscillate between 6 and $20^{\circ} \mathrm{C}$ in the Leones Island ( $\left.45^{\circ} 10^{\prime} \mathrm{S}\right)$ and between 1.2 and $15^{\circ} \mathrm{C}$ in Blanco Cape $\left(47^{\circ} 20^{\prime} \mathrm{S}\right)$. There are 2 management areas, limited by $46^{\circ} \mathrm{S}$ : Provinces of Chubut and Santa Cruz. The jurisdictions of these provinces extend for approximately $24 \mathrm{~km}(12 \mathrm{~nm})$ outside the gulf. Towards the east, the adjacent area is under National jurisdiction. This area was included in this study because it is directly linked to the management of the gulf. In the jurisdiction of the Chubut province, a restricted fishing effort area has been established near Comodoro Rivadavia city. Only vessels with lengths less than $21 \mathrm{~m}$ operate in this area (Fig. 1).

\section{Fleet Characterization}

Three different fishing fleets operate in SJG: a- doublebeam trawler fleet, b- high-sea ice trawler fleet and c- a coastal fleet. The program of observers on board of Chubut province $(\mathrm{POBCh})$ monitors these 3 fleets.

${ }^{1}$ Alarcón R, M Avellanal, C Bravo \& D Gorny. 2003. Langostino de los canales (M unida subrugosa) una alternativa productiva en la Región de Magallanes. FONDEF D00I- 1181. Universidad de Magallanes, Chile, 24 pp. 


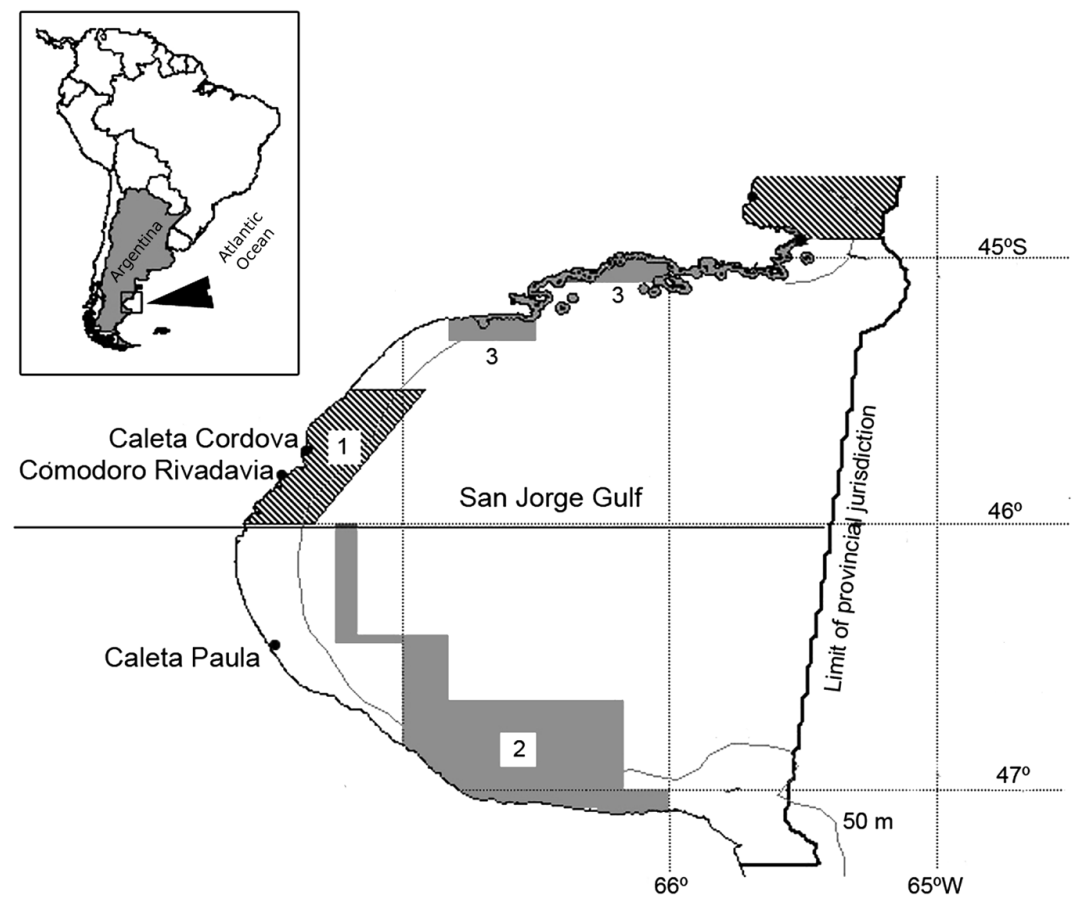

Figure 1. San Jorge Gulf, Southwestern Atlantic Ocean. 1.- Restricted fishing effort area. 2.- Closure of Mazarredo. 3.- Temporal closures in northern gulf / Golfo San Jorge, Océano Atlántico sudoccidental. 1.- Área de esfuerzo pesquero restringido. 2.- Área de veda de Mazarredo. 3.- Áreas de cierres temporales en el norte del golfo
The Patagonian shrimp is the target species of doublebeam trawler fleet (Boschi 1997, Góngora et al. 2012). This fleet is comprises 80 vessels with lengths approximately between 23 and $50 \mathrm{~m}$, provided of 2 trawling nets with a mesh size of $45 \mathrm{~mm}$ in the codend. The nets have vertical openings of 1.2-1.5 m and horizontal openings of 30-50 m. The fishery begins in the Santa Cruz area in FebruaryMarch. During autumn and winter, the fleet follows the migration of the resource to the central - eastern gulf and towards national waters. During spring, the fleet moves to the north of the gulf, where it remains until the closure of the fishing season in November-December. The low availability of the resource can determine mid-season closures (Góngora et al. 2012).

The high-sea ice fleet includes about 20 vessels with lengths larger than $21 \mathrm{~m}$. The hake Merluccius hubbsi Marini is the main target species of this fleet. Vessels use a bottom trawl with a mesh size of 100-120 $\mathrm{mm}$ in the codend. The fishery is open all year, but the area of fleet operation varies seasonally. In autumn and winter, it takes place in the central area of the gulf, whereas in spring and summer, the fleet operates in the northern gulf (Góngora et al. 2012).

The coastal fleet includes vessels with lengths ranging from 8 to $21 \mathrm{~m}$. Within this range, smaller vessels use a single trawl net, whereas the larger vessels use 2 fishing nets like those of the double-beam trawler fleet. This fleet is composed of 4-10 vessels that use a net of $40 \mathrm{~mm}$ mesh when the target species is the Patagonian shrimp and a net of $100 \mathrm{~mm}$ mesh when the target species are the hake or the southern king crab Lithodes santolla (Molina). In the Chubut province jurisdiction in the SJG, the coastal fleet operates mainly in a restricted fishing effort area.

\section{Data collection}

The observers of the POBCh monitored squat lobster bycatch in hauls of the double-beam trawler fleet between 2001 and 2011, in hauls of the high-sea ice trawler fleet between 2001 and 2008, and in hauls of the coastal fleet in SJG between 2009 and 2011. The presence of squat lobster and its relative abundance was recorded according to the following scale: a- rare (squat lobsters in less than $5 \%$ of the capture in terms of number of individuals), bcommon (5 to $25 \%$ ), c- abundant (25 to $50 \%$ ) and d- very abundant (over 50\%). The frequency of occurrence [FO $=($ hauls with presence of $M$. gregaria/total of hauls $) *$ $100 \%$ ] was calculated for different management units, depths, years and months. The fate of the captures was recorded as: a- fully boxed, b- partially boxed and cdiscarded. For coastal fleet, independence of FO respect to depth and target species was evaluated. 


\section{Data Analysis}

The GVSIG 10.1 program was used for the geographical analysis of data. The nautical chart of SJG (Servicio de Hidrografía Naval) was georeferenced (datum WGS 84) and used for the mapping of hauls. The management units and the isobaths of 50 and $90 \mathrm{~m}$ were incorporated in the nautical chart. A 6' x 6' grid was used to represent the relative abundance (RA) of squat lobsters in the hauls of double-beam trawler fleet. For this, RA was transformed as ordinal variables ( 0 : absent, 1: rare, 2: common, 3 : abundant, 4: very abundant).

The non-parametric Chi-square test was used to analyze independence between FO and RA and different factors such as fleet, management unit, depth $(<50 \mathrm{~m}$ and $>50 \mathrm{~m}$ ) and target species. Yates correction was used in order to improve the accuracy of the null-condition sampling distribution of chi-square (Zar 2010).

\section{Results}

\section{DOUble-bEAM TRAWLER FLEET}

Between January 2001 and June 2011, 63579 hauls of double-beam trawler fleet were monitored. The FO was $47.05 \%$, but there were significant monthly and spatial variations. The highest frequencies were observed during the summer, while the lowest ones were observed during autumn (Table 1). A significant annual increase in the FO during the period analyzed was also observed. The FO was higher in the Chubut (Cht) jurisdiction than in the National (Nat) and the Santa Cruz (SCz) jurisdictions (Table 2). FO was related with depth in Cht jurisdiction $\left(\chi^{2}=2927,6, \mathrm{df}=1, P<0,01\right)$, higher values of FO were recorded in coastal waters with depths shallower than 50 $\mathrm{m}$. Independence tests between FO and depth were not done for $\mathrm{SCz}$ and $\mathrm{Na}$ jurisdictions. In the $\mathrm{SCz}$ jurisdiction, the coastal depth stratum $<50 \mathrm{~m}$ is, to a large extent, within the closure area of Mazarredo (see Fig.1), while the National jurisdiction does not include depths lower than $50 \mathrm{~m}$.

\begin{tabular}{|c|c|c|c|c|c|c|c|c|c|c|c|c|}
\hline 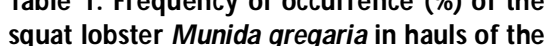 & & 2001 & 2002 & 2003 & 2004 & 2005 & 2006 & 2007 & 2008 & 2009 & 2010 & 2011 \\
\hline double-beam trawler fleet in San Jorg & Jan & - & 80.60 & 96.00 & - & - & - & 100 & - & - & - & - \\
\hline Argentina / Frecuencia de ocurrencia (\%) de & Feb & 31.56 & 69.84 & 69.84 & 14.77 & 78.24 & - & 100 & 93.04 & 68.12 & - & - \\
\hline la langostilla Munida gregaria en lances de & Mar & 13.10 & 27.12 & 77.12 & 27.98 & 91.38 & - & 59.15 & 26.70 & 96.20 & 74.25 & 74.50 \\
\hline la flota congeladora tangonera en el Golfo & Apr & 6.48 & 5.25 & 5.24 & 5.71 & 99.17 & 35.69 & 12.33 & 26.91 & 36.50 & 88.20 & 86.82 \\
\hline San lorge Argentina & May & 1.50 & 1.43 & 1.43 & 39.54 & 0 & 17.91 & 26.25 & 56.52 & 52.90 & 93.60 & 85.39 \\
\hline Jorge, Argentina & Jun & 1.29 & 2.13 & 2.13 & 69.13 & - & 23.80 & 26.36 & 28.74 & 13.46 & 56.26 & 60.00 \\
\hline & Jul & 1.68 & 15.67 & 15.67 & 59.35 & - & 9.65 & 30.08 & 37.27 & 44.67 & 73.88 & - \\
\hline & Aug & 2.34 & 38.64 & 38.64 & 45.54 & - & 7.60 & 45.26 & 12.37 & 21.48 & 70.28 & - \\
\hline & Sep & 0 & 31.40 & 31.40 & 65.84 & 62.93 & 20.40 & 37.07 & 53.50 & 34.88 & 69.17 & - \\
\hline & Oct & 0 & 42.48 & 42.48 & 100 & 82.40 & 52.20 & 58.43 & 85.13 & 42.84 & 92.78 & - \\
\hline & Nov & 39.90 & 37.32 & 37.32 & 89.76 & 81.47 & - & - & 98.73 & 64.62 & 85.69 & - \\
\hline & Dec & 13.12 & 53.87 & 53.87 & 0 & - & - & 62.06 & 100 & 91.88 & 93.96 & - \\
\hline
\end{tabular}

Table 2. Frequency of occurrence (FO, \%) of the squat lobster M unida gregaria in hauls of double-beam trawler fleet in different management units of San Jorge Gulf. N, total hauls. $\chi^{2}$ and probability values $(P)$ of rejecting the null hypothesis of independence between $\mathrm{FO}$ and management unit for each years analyzed. $d f=2$ / Frecuencia de ocurrencia (FO, \%) de la langostilla M unida gregaria en lances de la flota congeladora tangonera en las diferentes unidades de manejo del Golfo San Jorge, Argentina. $\chi^{2}$ y valor de probabilidad asociada $(P)$ del testeo de la hipótesis de independencia entre FO y la unidad de manejo para cada año analizado. Grados de libertad $=2$

\begin{tabular}{crrrrrrrr}
\hline & \multicolumn{2}{c}{ Chubut } & \multicolumn{2}{c}{ Santa Cruz } & \multicolumn{2}{c}{ National } & \multirow{2}{*}{$\chi^{2}$} & $P$ \\
\cline { 2 - 6 } & \multicolumn{1}{c}{ FO } & $\mathrm{N}$ & \multicolumn{1}{c}{ FO } & \multicolumn{1}{c}{$\mathrm{N}$} & \multicolumn{1}{c}{ FO } & \multicolumn{1}{c}{$\mathrm{N}$} & & \\
\hline 2001 & 28.9 & 2008 & 3.5 & 860 & 2.8 & 345 & 302.5 & $<0.01$ \\
2002 & 50.2 & 3357 & 4.8 & 4090 & 10.1 & 3003 & 2599 & $<0.01$ \\
2003 & 61.5 & 1954 & 4.5 & 2589 & 19.7 & 3227 & 2011 & $<0.01$ \\
2004 & 78.5 & 5987 & 10.4 & 1995 & 27.8 & 1612 & 3444 & $<0.01$ \\
2006 & 37.4 & 2264 & 15.5 & 1735 & 0.4 & 938 & 596.8 & $<0.01$ \\
2007 & 65.5 & 1650 & 18.1 & 1301 & 26.8 & 674 & 740 & $<0.01$ \\
2008 & 80.7 & 4489 & 52.4 & 1403 & 33.9 & 1319 & 2139 & $<0.01$ \\
2009 & 80.8 & 5456 & 87.6 & 1133 & 82.4 & 1004 & 1149 & $<0.01$ \\
2010 & 80.8 & 3974 & 87.6 & 633 & 82.4 & 1438 & 17.7 & $<0.01$ \\
2011 & 90.0 & 1929 & 79.5 & 461 & 87.5 & 751 & 40.6 & $<0.01$ \\
Overall & 69.7 & 33068 & 17.1 & 16200 & 28.4 & 14351 & 14685 & $<0.01$ \\
\hline
\end{tabular}



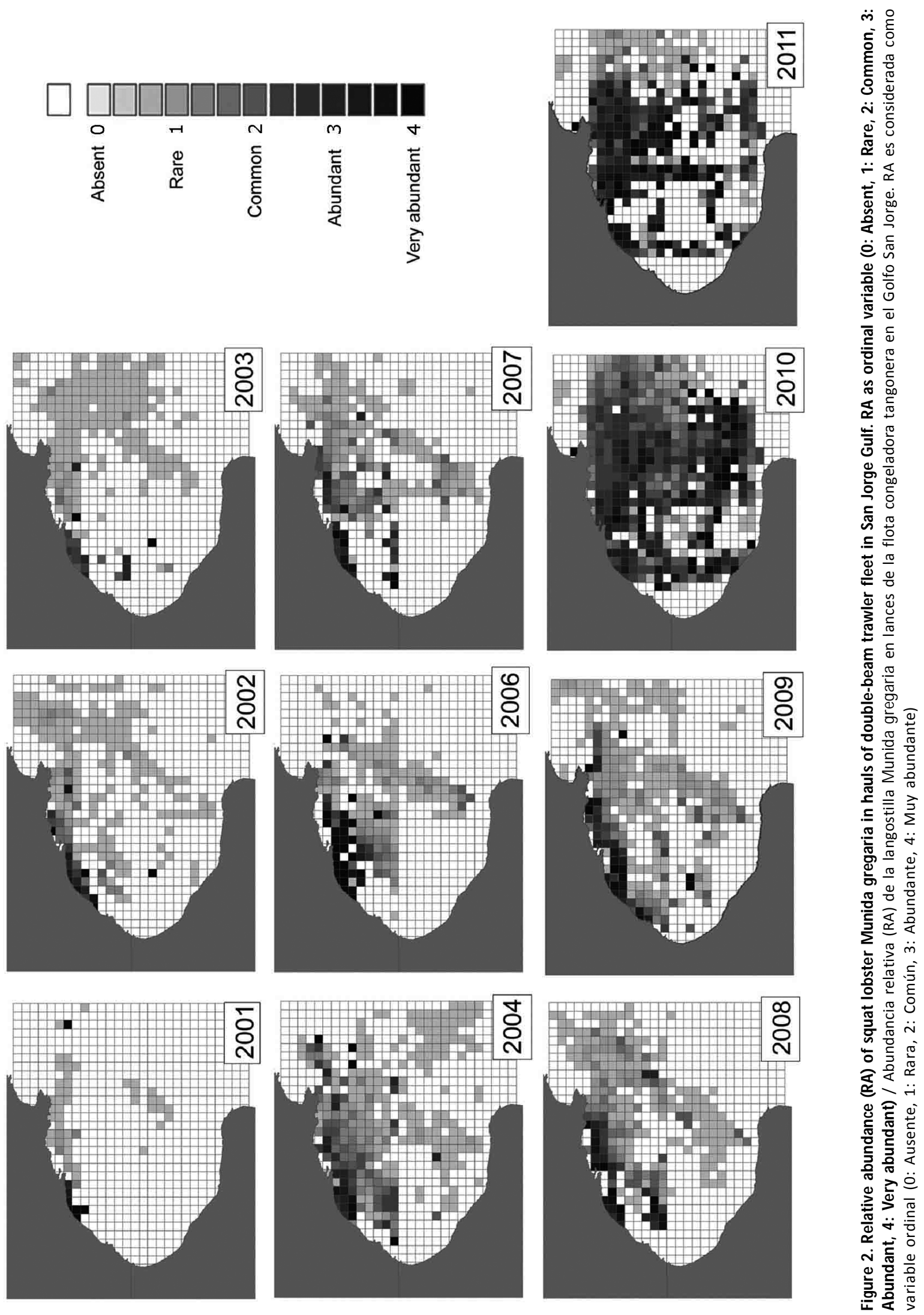

Vol. 50, № 2, 2015 253 
Relative abundance of $M$. gregaria was higher in Cht area during the whole period. In the $\mathrm{SCz}$ and Nat areas, a lower abundance of $M$. gregaria captures was observed between 2001 and 2009. However, a significant increase in the FO and RA was recorded in these areas in the last years (Fig. 2). In the $\mathrm{SCz}$ area, the incidental catch of squat lobster was concentrated near the closure area of Mazarredo. An interannual increase was also recorded in the Cht area, where the squat lobster was the main component of the capture in $40 \%$ of the hauls of Patagonian shrimp during 2011.

\section{High-SEA ICE FLEET}

Between January 2001 and December 2008, 5608 hauls were monitored in the hake fishery. The hauls analyzed were concentrated in the Chubut jurisdiction. The annual average for the period was $37.42 \%$. The highest values of FO were recorded during spring and summer, when the fleet was operating in the north of SJG. An increase in FO was recorded in recent years (Table 3). In the hake fishery, the RA of squat lobsters was low. The species was rare in most of the hauls in which it was present. The highest values of RA were recorded in coastal areas, mainly in the northern part of the gulf and near the restricted fishing effort area. In the $\mathrm{SCz}$ area, the rare category was only represented (Fig. 3).

Table 3. Frequency of occurrence (\%) of the squat lobster Munida gregaria in hauls of the high-sea ice trawler fleet in San Jorge Gulf, Argentina / Frecuencia de ocurrencia (\%) de la langostilla Munida gregaria en lances de la flota fresquera de altura en el Golfo San Jorge, Argentina

\begin{tabular}{lcccccccc}
\hline & 2001 & 2002 & 2003 & 2004 & 2005 & 2006 & 2007 & 2008 \\
\hline Jan & 8 & 32.14 & 14.25 & 0 & 0 & 96.42 & 94.04 & 96.00 \\
Feb & - & 32.22 & 12.65 & 0 & - & 62.93 & 95.83 & 96.15 \\
Mar & 4.76 & 44.82 & 17.76 & 0.64 & 0 & 44.31 & 61.53 & 73.19 \\
Apr & 77.77 & 25.78 & 3.25 & 4.81 & 0 & 83.33 & 40.92 & 70.00 \\
May & - & 45.31 & 13.88 & 0 & 0 & 77.00 & 100 & 3.22 \\
Jun & 69.04 & & 28.00 & - & 0 & 100 & 62.50 & 11.11 \\
Jul & - & 16.00 & 0 & - & 0 & - & - & 0 \\
Aug & - & 18.91 & 24.63 & - & 0 & - & - & - \\
Sep & 0 & 55.93 & 2.00 & - & 19.10 & 96.15 & - & - \\
Oct & 47.06 & 16.00 & 5.93 & - & 0 & - & 0 & - \\
Nov & 24.44 & 33.11 & 0 & - & 100 & 89.65 & - & 50 \\
Dec & 40.36 & 7.54 & 0 & 0 & 0 & 100 & - & 100 \\
\hline
\end{tabular}
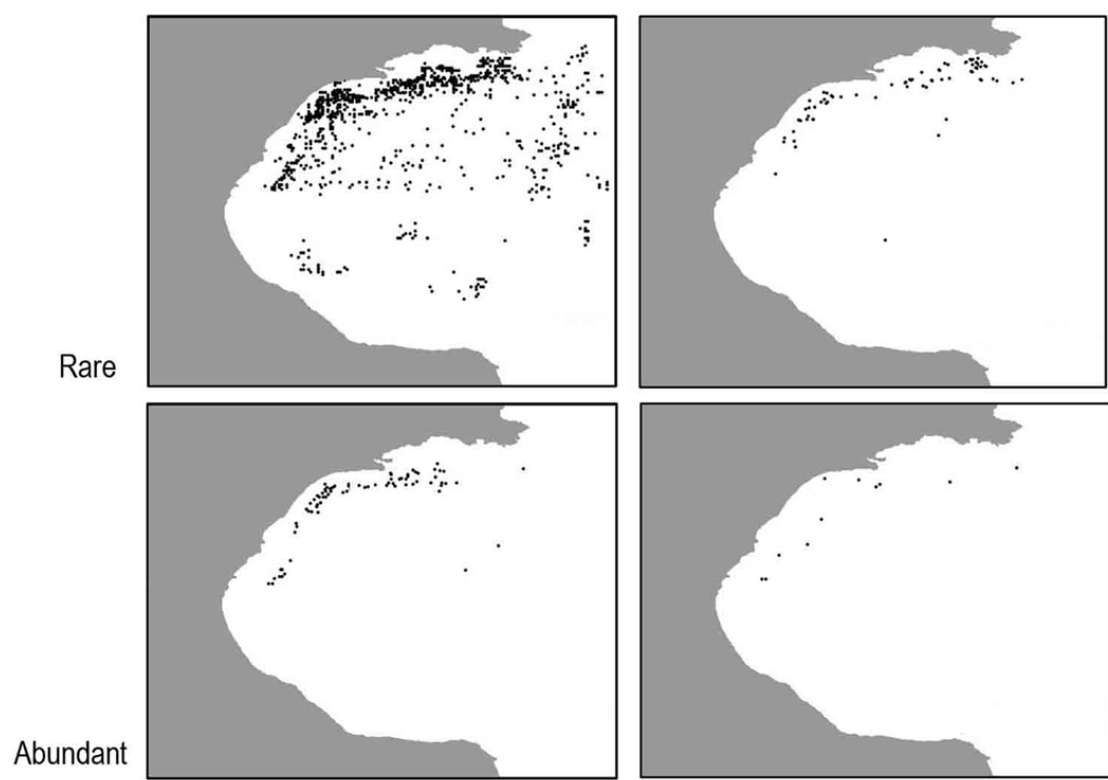

Common

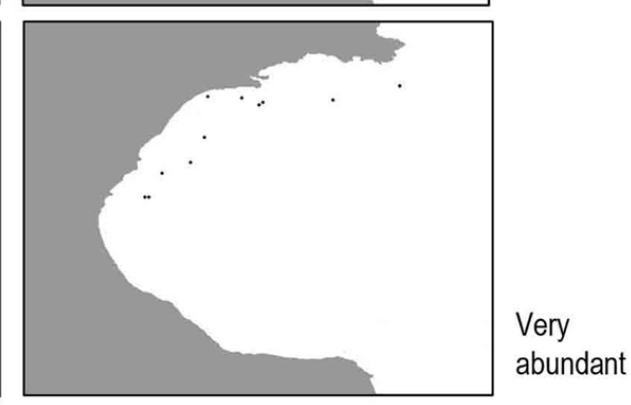

Figure 3. Hauls of high-sea ice trawler fleet grouped according to squat lobster M unida gregaria relative abundances in San Jorge Gulf / Lances de la flota fresquera de altura agrupados de acuerdo a la abundancia relativa de la langostilla Munida gregaria en el Golfo San Jorge 


\section{Coastal fleet}

Between January 2008 and December 2010, 584 hauls of this fleet were monitored. In the restricted fishing effort area, the species was observed in $88.6 \%$ of the hauls. The FO was high during the entire period, independently of the depth or the target species of the fishery (Table 4).

The RA was higher in coastal waters $(<50 \mathrm{~m})$, where the species represented over $25 \%$ of the capture in over half of the hauls (Fig. 4). The RA was lower when the hake was the target species (Fig. 5). In these hauls, the rare category was the best represented. An increase in squat lobster abundance was observed in the June and July hauls in different years. When the target species was the Patagonian shrimp, the hauls in which the squat lobster represented $25 \%$ of the total capture prevailed. This tendency in the RA concerning depths and target species can be generalized for the entire period. However, in 2008, abundant squat lobsters catches in offshore areas were observed. In 2009, the species was dominant in most of the hauls concentrated in the shore area in front of Caleta Cordova. The RA in 2010 was lower than in the previous years, probably because a few hauls were made in the shore water under $50 \mathrm{~m}$ depth.
Table 4. Frequency of occurrence ( $\mathrm{FO}, \%)$ of the squat lobster Munida gregaria in hauls of the coastal fleet in San Jorge Gulf. $\chi^{2}$ and probability values $(P)$ of rejecting the null hypothesis of independence between FO and factors (target and depth) / Frecuencia de ocurrencia (FO, \%) de la langostilla M unida gregaria en lances de la flota costera en el Golfo San Jorge, Argentina. $\chi^{2}$ y valor de probabilidad asociada ( $P$ ) del testeo de la hipótesis de independencia entre FO y los factores (especies objetivo y profundidad)

\begin{tabular}{llrrccc}
\hline & & $\begin{array}{c}\text { Hauls } \\
+\end{array}$ & $\begin{array}{c}\text { Total } \\
\text { hauls }\end{array}$ & $\begin{array}{l}\text { FO } \\
(\%)\end{array}$ & $\chi^{2}$ & $P$ \\
\hline $\mathbf{2 0 0 8}$ & Hake & 61 & 64 & 95.3 & 3.97 & 0.04 \\
& Shrimp & 54 & 54 & 100 & & \\
& $<50 \mathrm{~m}$ & 15 & 15 & 100 & 1.04 & 0.30 \\
& $>50 \mathrm{~m}$ & 100 & 104 & 96.1 & & \\
$\mathbf{2 0 0 9}$ & Hake & 160 & 193 & 82.9 & 0.41 & 0.51 \\
& Shrimp & 146 & 171 & 85.3 & & \\
& $<50 \mathrm{~m}$ & 71 & 78 & 91.0 & 3.82 & 0.50 \\
& $>50 \mathrm{~m}$ & 234 & 286 & 81.8 & & \\
$\mathbf{2 0 1 0}$ & Hake & 48 & 48 & 100 & 0.66 & 0.41 \\
& Shrimp & 40 & 42 & 95.2 & & \\
& $<50 \mathrm{~m}$ & 7 & 7 & 100 & 0.14 & 0.70 \\
& $>50 \mathrm{~m}$ & 81 & 85 & 95.2 & & \\
\hline
\end{tabular}

Figure 4. Relative abundance (RA) of squat lobster Munida gregaria in hauls of the coastal fleet in San Jorge Gulf, grouped according to depth. $\chi^{2}$ and probability values $(P)$ of rejecting the null hypothesis of independence between RA and depth. $\mathbf{d f}=\mathbf{4}$ / Abundancia relativa (RA) de la langostilla Munida gregaria en lances de la flota costera en el Golfo San Jorge, de acuerdo a la profundidad. $\chi^{2}$ y valor de probabilidad asociada $(P)$ de la prueba de la hipótesis de independencia entre RA y la Unidad de Manejo para cada año analizado. Grados de libertad $=4$

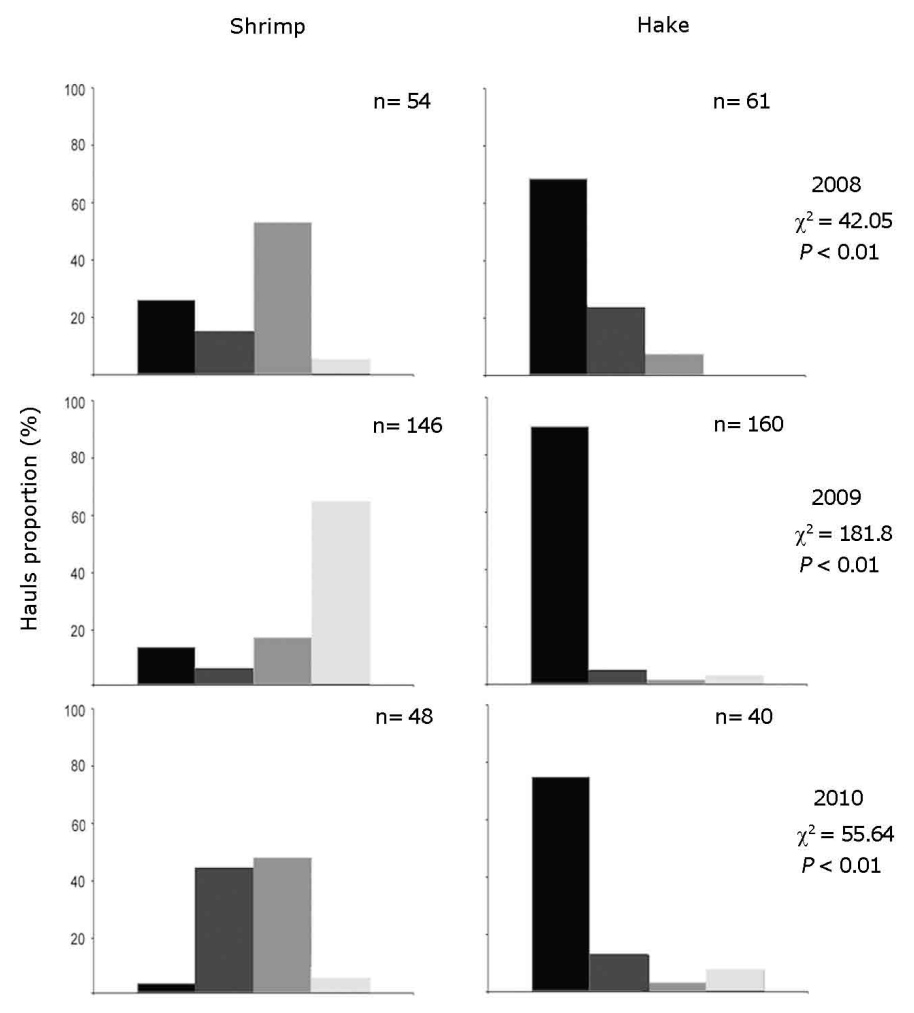

- Rare घ Common $\|$ Abundant $\llbracket$ Very abundant 
Figure 5. Relative abundance (RA) of squat lobster Munida gregaria in hauls of the coastal fleet in San Jorge Gulf, grouped according to target species of the fleet. $\chi^{2}$ and probability values $(P)$ of rejecting the null hypothesis of independence between RA and depth. $\mathbf{d f}=\mathbf{4}$ / Abundancia relativa (RA) de la langostilla Munida gregaria en lances de la flota costera en el Golfo San Jorge, de acuerdo a la especie objetivo de la flota. $\chi^{2}$ y valor de probabilidad asociada $(P)$ de la prueba de la hipótesis de independencia entre RA y la Unidad de Manejo para cada año analizado. Grados de libertad $=4$

\section{Discussion}

The squat lobster Munida gregaria is an important species of bycatch in trawling fisheries of SJG. Variations in the frequency of occurrence and relative abundance of this species in the hauls between fleets are related to the different fishing nets used, depth and operation areas. Given the size of the double-beam trawler fleet, the effort level suggests that the highest captures in terms of biomass are obtained by this fleet. However, in terms of FO and RA, the highest squat lobster catches were recorded in the coastal fleet.

The high abundance of $M$. gregaria in SJG has been mentioned in previous papers (Vinuesa 2007, Varisco \& Vinuesa 2007). Squat lobster Munida gregaria is the most important crustacean in the bycatch of Patagonian shrimp fishery. Roux \& Piñero (2006) indicated that the highest concentrations of squat lobsters occur in the central and southern areas of the gulf. However, these authors did not consider samples of the coastal waters in the north of the gulf, where the relative abundance of

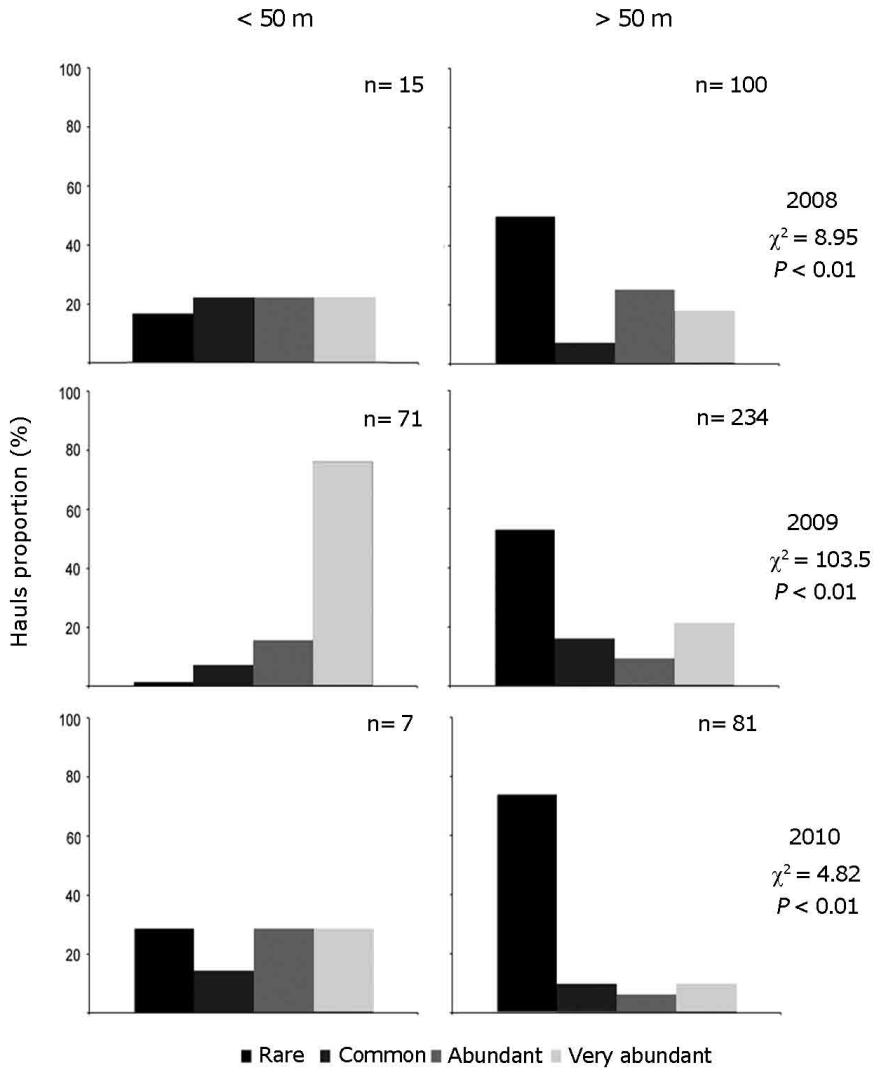

squat lobsters in hauls is higher. In this study, the main incidental catches of the species were recorded in the coastal area of the northern sector of the gulf. This difference may be explained by the fact that the highest abundance of squat lobster was observed in waters with depths shallower than 50 m. In Santa Cruz, the coastal fringe of low depth is, to a large extent, within the closure area of Mazarredo (Fig. 1). Since the National jurisdiction does not include coastal waters, a low RA is expected.

Until 2009, the squat lobster bycatch in the Patagonian shrimp fishery had a concentrated spatial pattern, with the exception of 2005; this year the number of fishing hauls was low because of the strong temporal and spatial restrictions in response to a decrease in shrimp abundance. A diffuse spatial pattern was observed in 2010 and 2011. An increase in the relative abundance of the species was observed after 2008. This increase was more significant in the jurisdictions of Santa Cruz and Nation. Ravalli et al. $(2010)^{2}$ also indicated that the abundance of

${ }^{2}$ Ravalli C, L López-Greco \& J de la Garza. 2010. Abundancia y distribución de los morfotipos gregaria y subrugosa de la langostilla Munida gregaria (Decapoda, Galatheidae) en el Golfo San Jorge. Informe Técnico INIDEP 45: 1-21. 
squat lobster in SJG was significantly higher in 2010 than in 2009. This increase is associated with a demographic expansion of squat lobsters. The causes for this expansion has not been established yet, but several aspects can be considered to explain it: a) a lower abundance of hake, which in terms of biomass is the main predator of the species in SJG (Vinuesa \& Varisco 2007), b) an increase in the food availability in the water column for the larval stages and the occurrence of pelagic juveniles in the gulf, which allowed the species to enhanced its trophic niche and habitat (Varisco \& Vinuesa 2010), and c) a slight increase in the fecundity of the species concerning the previous available values for the 2009-2010 period (Varisco 2013). However, a sustained monitoring of the fecundity is necessary to determine whether this increase is a tendency or a response of interannual fecundity oscillations.

Population growth of $M$. gregaria is perceived as a problem for the shrimp fishery management and fishermen, because it can reduce the capture and cause loss of quality of shrimp. However, this growth did not significantly affect the development of the fishery. In the period 2009-2011 there were significant catches and high revenues for the fishery (Fig. 6). Fisheries statistics suggest that population growth of squat lobster does not affect the shrimp landings and the fishery profits in the short term. Moreover, considering that the shrimp has a short life cycle (2-3 years), the effects of $M$. gregaria population growth should have already appeared in the fishery. However, further studies should be conducted to assess the interaction of the lobster and shrimp, and their possible long-terms effects on the fishery.

The frequency of occurrence and relative abundance of squat lobster in the hauls of the high-sea ice fleet was low. This is related to the fact that these vessels use nets with a larger mesh $(100 \mathrm{~mm})$ than the ones used by the double-beam trawler fleet and operate in areas far from the coast most of the year. Just like in the shrimp fishery, the main incidental catches of squat lobster occur in the coastal area in the northern part of the gulf. Given the low abundance of squat lobster, this is not a major problem in the hake fishery, but also represents a potential resource for the high-sea ice trawler fleet.

In the coastal fleet, the highest squat lobster FO and RA were mainly due to the exclusive operation in restricted fishing effort area in coastal waters. The seasonal variations in RA would be related to the fishing nets used and the demographic dynamics of $M$. gregaria. The
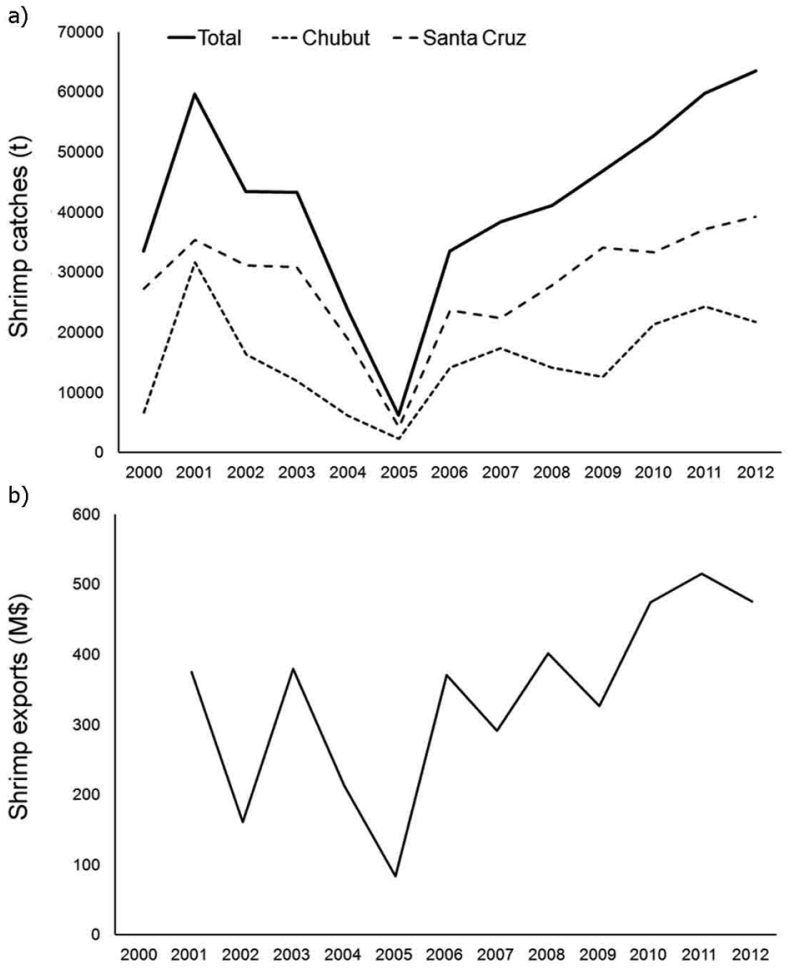

Figure 6. a) Patagonian shrimp catches (t) of double-beam trawler fleet between 2000 and 2012. b) Argentinian exports of patagonian shrimp, between 2001 and 2012, in millions of dollars (MUS\$) / a) Capturas de langostino patagónico $(t)$ de la flota congeladora tangonera entre 2000 y 2012. b) Exportaciones argentinas de langostino patagónico expresadas en millones de dólares (MUS\$) en el periodo 2001-2012

bycatch of the species was higher during the months in which the Patagonian shrimp was the target species. The smaller mesh size $(40 \mathrm{~mm})$ and the lower depths favored the capture of squat lobsters in this period. On the other hand, the increase in the FO recorded in June-July can be related to the aggregation of squat lobsters in the coastal areas at the beginning of the reproductive period. This has been reported in several squat lobsters species and was previously observed in SJG (Vinuesa 2007). In these months, the target species is the hake (mesh $100 \mathrm{~mm}$ ), which explains the low RA in spite of the high FO.

The results show that the squat lobster is an abundant and so far not exploited resource in the coastal areas of SJG. The potentially commercial exploitation of the species was evaluated in the Magellan Strait, using traps for its capture (Alarcón et al. 2003). This activity has been suggested in several locations within the distribution range of the species (Zeldis 1985, Vinuesa 1990, Lovrich 
et al. 1999), mainly encouraged by the abundance of the species. However, it is important to consider that the squat lobster is prey of a large number of fishes, mollusks, crustaceans, birds and mammals, many of them of commercial importance (Zeldis 1985, Romero et al. 2004, Vinuesa \& Varisco 2007). For this reason, the exploitation of these specimens could have important implications in the benthic and demersal community of the gulf. Zeldis (1985) indicated that the potential fishery of $M$. gregaria in New Zealand must be developed in a minor scale to minimize the impact on the ecosystem. Tapella (2002) also indicated that the squat lobster fishery in the Beagle Channel should be extremely conservative. In SJG, the squat lobster represents an alternative resource for the coastal fleet, because it operates in coastal areas where the resource is abundant, has lower operational costs and its catches are destined for small fishing plants that may have a higher interest in the resource. Integral use of the species can help alleviate the fishing industry crisis in SJG. However, commercial exploitation must be limited to specimens caught as bycatch. A direct fishery is not advisable from an ecological perspective, given that the species has a key role in the marine ecosystem.

\section{ACKNOWLEDGMENTS}

We thank Marcelo Sosa and Cristina Masera for their collaboration in geographical analysis. This work was partially founded by PI UNPSJB 'Bases biológicas para el aprovechamiento de la langostilla Munida gregaria en el Golfo San Jorge' and by a PICTO ( $\mathrm{N}^{\circ}$ 36972) from the National Agency for Promotion of Science and Technology (ANPCyT), Argentina.

\section{LITERATURE CITED}

Andrew N \& J Pepperell. 1992. The by-catch of shrimp trawl fisheries. Oceanographic and Marine Biology: An Annual Reviews 30: 527-556.

Aurioles-Gamboa D \& E Balart. 1995. La langostilla: Biología, ecología y aprovechamiento, 233 pp. Centro de Investigaciones Biológicas del Noroeste, México.

Bergmann M \& P Poore. 2001. Survival of decapod crustaceans in the nephros fishery of the Clyde Sea area, Scotland. ICES Journal of Marine Science 58: 163-171.

Boschi E. 1997. Las pesquerías de crustáceos decápodos en el litoral de la República Argentina. Investigaciones Marinas 25: $19-40$.

CSIC. 2014. El CSIC valoriza, para su uso comercial en la alimentación humana, animal y la medicina, especies descartadas por la flota gallega. Consejo Superior de Investigaciones Científicas, España. <www.iim.csic.es/ Documentos/Act_34_18.pdf>
FAO. 2003. La ordenación pesquera 2 . El enfoque de ecosistemas en la pesca. FAO Orientaciones Técnicas para la Pesca Responsable 4 (Supl. 2): 1-133.

Góngora M, D González-Zevallos, A Pettovello \& A Mendía. 2012. Caracterización de las principales pesquerías del golfo San Jorge Patagonia, Argentina. Latin-American Journal of Aquatic Research 40: 1-11.

Kelleher K. 2008. Descartes en la pesca de captura marina mundial. FAO Documento Técnico de Pesca 470: 1-147.

Lovrich G, M Casalinuovo, S Molina, C Cárcamo \& R Pierotti. 1999. Las langostillas Munida subrugosa y $M$. gregaria (Decapoda, Anomura) como potencial recurso económico patagónico. Naturalia Patagónica 6: 89-92.

Palma E, R Matano \& A Piola. 2008. A numerical study of the Southwestern Atlantic Shelf circulation: Stratified ocean response to local and offshore forcing. Journal of Geophysical Research 113: C11010. <doi:10.1029/ 2007JC004720>

Pettovello A. 1999. By-catch in the Patagonian red shrimp (Pleoticus muelleri) fishery. Marine and Freshwater Research 50: 123-127.

Rodríguez L \& R Bahamonde. 1986. Contribución al conocimiento de Munida subrugosa (White 1847) en la XII Región, Chile. En: Arana P (ed). La pesca en Chile, pp 283-296. Universidad Católica de Chile, Valparaíso.

Romero M, G Lovrich, F Tapella \& S Thatje 2004. Feeding ecology of the crab Munida subrugosa (Decapoda: Anomura: Galatheidae) in the Beagle Channel, Argentina. Journal of Marine Biological Association of United Kingdom 84: 359-365.

Roux A \& R Piñero. 2006. Crustáceos decápodos y Estomatópodos asociados a la pesquería del langostino patagónico Pleoticus muelleri (Bate, 1888) en el Golfo San Jorge, Argentina. Revista de Investigaciones y Desarrollo Pesquero 18: 33-43.

Sato S. 1974. Development of pelagic red crab (Galatheidae, Pleuroncodes planipes) fishery in the Eastern Pacific Ocean. Marine Fisheries Review 36: 1-9.

Stobuzki I, M Miller, P Jones \& P Salini. 2001. Bycatch diversity and variation in a tropical Australian penaeid fishery, the implications for monitoring. Fisheries Research 53: 283-301.

Tapella F. 2002. Reproducción, crecimiento, distribución y abundancia de la langostilla Munida subrugosa (Anomura: Galatheidae) del canal Beagle, Tierra del Fuego, Argentina. Tesis Doctoral, Universidad Nacional de Córdoba, Córdoba, 147 pp.

Varisco M. 2013. Biología de Munida gregaria (Crustacea Anomura): bases para su aprovechamiento pesquero en el Golfo San Jorge, Argentina. Tesis Doctoral, Universidad Nacional de La Plata, La Plata, 161 pp.

Varisco M \& J Vinuesa 2007. La alimentación de Munida gregaria en fondos de pesca en el Golfo San Jorge. Revista de Biología Marina y Oceanografía 42: 221-229. 
Varisco M \& J Vinuesa. 2010. Occurrence of pelagic juveniles of Munida gregaria (Fabricius, 1793) in San Jorge Gulf, Argentina. Crustaceana 83: 1147-1151

Vinuesa J. 1990. Los recursos marinos renovables de la Tierra del Fuego I. Moluscos y crustáceos. Contribución Científica Centro Austral de Investigaciones Científicas 11: 1-34.

Vinuesa J. 2007. Reproduction of Munida gregaria (Decapoda: Galatheidae) in San Jorge Gulf, southwest Atlantic Ocean. Journal of Crustacean Biology 27: 437-444.

Vinuesa J \& M Varisco. 2007. Trophic ecology of the lobster krill Munida gregaria in San Jorge Gulf, Argentina. Investigaciones Marinas 35: 25-34.
Wehrtmann I \& E Acuña. 2011. Squat lobsters fisheries. In: Poore G, S Ahyong \& J Taylor (eds). The biology of squat lobsters, pp. 297-322. CSIRO Publishing / CRC Press, Melbourne.

Zar J. 2010. Biostatistical analysis, 944 pp. Pearson PrenticeHall, Upper Saddle River.

Zeldis J. 1985. Ecology of Munida gregaria (Decapoda, Anomura): distribution and abundance, population dynamics and fisheries. Marine Ecology Progress Series 22: 77-99.

Received 3 June 2014 and accepted 19 March 2015

Editor: Claudia Bustos D. 